\title{
RISK FACTORS PULMONARYTUBERCULOSIS IN POASIA HEALTH CENTRES IN THE COASTAL REGION OF KENDARI CITY
}

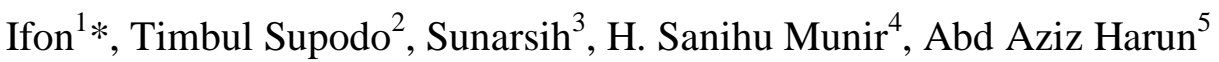 \\ ${ }^{1,2,3,4}$ Universitas Mandala Waluya, in Kendari Southeast Sulawesi Province, Indonesia
}

Corresponding Author : Ifon

Email : ifonzaharani@gmail.com

\section{Abstract}

Background:Tuberculosis or pulmonary tuberculosis is an infectious disease caused by the presence of the bacteria Mycobacterium Tubercolusis. Tuberculosis is a health problem. Kendari City prevalence is 3.53 per 1,000 population, especially in the work area of the Poasia Health centre, coastal area of Kendari City, every year there is a decrease, namely in 2017 as much 51 cases of lung TB smear positive, in 2018 as many50 cases of smear positive pulmonary TB and in 2019 as many49 cases of smear positive. However, this has not yet been able to achieve the National target, which is a minimum cure rate of $85 \%$. The research objective was to determine the risk factors for the incidence of smear positive pulmonary TB inPuskesmasPoasia in the coastal area of Kendari City.

Methods: This type of research is a case control Study conducted from December 2020 to January 2021, the sample used are 30 cases taken by random sampling and 30 controls.

Results: Using Odds Ratio (OR). OR valuehabit of cleaning mosquito nets OR = 9,036> 1 , cleaning or drying bedding or mattress $\mathrm{OR}=6,571>1$, Drop Out Treatment nno OR value, humidityOR $=6.909>1$, sunlight lighting $\mathrm{OR}=5,675>1$ and home ventilationOR $=4.030>1$.

Conclusion: Habit of cleaning mosquito nets, cleaning or drying bedding or mattress, moisture, sunlight lighting and home ventilation is a risk factor meanwhile drop out treatmentis not a risk factor for the incidence of smear positive pulmonary TB in PuskesmasPoasia in the coastal area of Kendari City.

Keywords: Pulmonary TB, Mosquito, Bedding, Humidity, Lighting, Ventilation. 
Ifon, Supodo, T., Sunarsih, Munir, S., \& Harun, A. A.

DOI: 10.36566/ijhsrd/Vol3.Iss1/68

https://ijhsrd.com/index.php/ijhsrd

e- ISSN: $\mathbf{2 7 1 5 - 4 7 1 8}$

\section{INTRODUCTION}

Tuberculosis is an infectious disease caused by Mycrobacterium Tuberculosis(1). Air pollution is not good one of the causes of lung disorders(2). Tuberculosis is a disease that has been known for a long time and is still a major problem of death worldwide(3).

Based on data from WHO (World Health Organization), it shows that tuberculosis causes the death of nearly 2,000 people every day. In addition, about $40 \%$ of Tuberculosis cases worldwide are in the Southeast Asia region. Indonesia ranks third in the world after India and China in terms of all cases of pulmonary tuberculosis, amounting to 583 thousand people and around 140 thousand people are estimated to die each year due to pulmonary tuberculosis(4).

Source from the profile of the Southeast Sulawesi Provincial Health Office in 2019, the prevalence rate of positive BTA TB cases was 3.96per 1,000 population. While the most new case findings reported in 2019 came from six districts, namely Kendari City with 711 cases with a prevalence of 3.53 per 1,000 population, South Konawe with 475 cases with a prevalence of 2.12 per 1,000 population, Bombana with 451 cases with prevalence 3.59 per 1,000 population, Konawe as many as 409 cases with a prevalence of 3.34 per 1,000 population, Kolaka as many as 402 cases with a prevalence of 2.75 per 1,000 population and Muna as many as 377 cases with prevalence of 3.95 per 1,000 population. The number of new cases in these six districts reached $>50 \%$ of the total new BTA positive cases in Southeast Sulawesi(5).

Judging by the prevalence data, Kendari City occupies the third level after Muna and Bombana, but in the last two years case detection in Kendari city continues to increase, namely in 2018 as many as 676 cases and in 2019 continued to increase to 711 so that the government tries to prevent the incidence of pulmonary tuberculosis the following year, there was no increase in cases again, more so in Kendari City. Other than that,Kendari City is an area where part of its territory consists of bay waters and mangrove vegetation, which have potential tourist attractions and can encourage community social and economic activities in Kendari City. Based on the aspect of the Regional Spatial Plan, the coastal bay of Kendari City is divided into trade and tourism zones (6).Apart from the unique geographical conditions, the Kendari City Bay Area is the gateway to Kendari City from the sea. Therefore, management planning and regional development of Kendari City must prioritize the characteristics of the sea, coastal areas and upstream areas(7). Aside from thatKendari City is on the Trans-Sulawesi route which is very dense and has high population mobility, so the entry and exit of the disease is not detected properly. The total population of Kendari City in 2019 is around 392,830 people(5).

Data from the Kendari City Health Office in 2017 found that the number of BTA positive sufferers was 538 cases or 1.45 per 1,000 population, in 2018 the number of positive AFB cases was 676 or 1.77 per 1,000 population, and in 2019 in Find the number of BTA positive sufferers as many as 711 or 1.80 per 1,000 population(8).

The public health center is as one of the first-level health service facilities has an important role in the national health system.(9) Based on data obtained from the Kendari City Office, the Puskesmas located in the coastal area include the Nambo Community Health Center, Poasia Community Health Center, Abeli Community Health Center and the Eye Health Center. PuskesmasPoasia ranks third in Kendari City after PuskesmasPuuwatu, and PuskesmasKemaraya in terms of the number of pulmonary TB patients. However, PuskesmasPoasia ranks first for coastal areas. So the researchers were interested in researching "Risk Factors Associated toprevalence of Pulmonary $\mathrm{TB}$ in the 
Ifon, Supodo, T., Sunarsih, Munir, S., \& Harun, A. A. DOI: 10.36566/ijhsrd/Vol3.Iss1/68

https://ijhsrd.com/index.php/ijhsrd

e- ISSN: $\mathbf{2 7 1 5 - 4 7 1 8}$

PuskesmasPoasia, the Coastal Region of Kendari City".

\section{METHOD}

The research method used is a quantitative method with a case control study design. To determine the risk factors between the independent variables and the dependent variable retrospectively at the Poasia Health Center which is located in the coastal area of the city of Kendari. The population of all patients suffering from pulmonary tuberculosis and seeking treatment at the Poasia Health Center in the coastal area of Kendari City was 49 patients. With a total sample of 30 cases and 30 controls (10). The variable in this study is the habit of cleaning the mosquito net, cleaning or drying bedding or mattress , Drop Out Treatment, humidity, sunlight lighting and home ventilation.Data analysis was carried out in several stages, namely descriptive, inferential analysis (11) and epidemiological analysis (Odd Ratio), and logistic regression(12). This analysis was carried out using the help of statistical applications.

\section{RESULTS}

Table 1 shows that 31 respondents have a habit of locking or drying the mosquito nets that are lacking, including 23 respondents $(74.2 \%)$ who were cases and 8 respondents $(25.8 \%)$ were controls. Then 29 respondents have a good habit of locking or drying the mosquito nets, including 7 respondents $(24.1 \%)$ who were cases and 22 respondents $(75.9 \%)$ were controls. The statistical test results show that the calculated chi square value $(\mathrm{X} 2 \mathrm{hit})=15.017>\mathrm{X} 2 \mathrm{tab}=$ 3.841 or $\mathrm{p}$ value $=0.000<0.05$, with a test value of closeness $(\varphi=0.500$. Also obtained the $\mathrm{OR}=9.036>1$. Logistic regression test resultsis 0.036 .

Table 2 shows that 33 respondents have the habit of cleaning or drying mattresses or bedding, including 23 respondents $(69.7 \%)$ who were cases and 10 respondents $(30.3 \%)$ were controls. Then 27 respondents have a good habit of locking or drying the mosquito nets, including 7 respondents $(25.9 \%)$ who were cases and 20 respondents $(74.1 \%)$ were controls.

The results of statistical tests show that the calculated chi square value (X2hit) = $11,380>\mathrm{X} 2 \mathrm{tab}=3,841$ or $\mathrm{p}$ value $=0,000$ $<0.05$, with a test value of closeness $(\varphi=$ $0.436)$, . Also obtained the $\mathrm{OR}=6,571>1$. Logistic regression test results that is 0.203

Table 3 shows that 31 respondents had incomplete treatment, including 1 respondent (3.2\%) who was a case and 30 respondents (96.8\%) who was a control. Then 29 respondents had complete treatment, including 29 respondents $(100.0 \%)$ who were cases and 0 respondents $(0.0 \%)$ who were controls. The statistical test results show that the calculated chi square value $(\mathrm{X} 2 \mathrm{hit})=56,129>\mathrm{X} 2 \mathrm{tab}=3,841$ or $\mathrm{p}$ value $=0.001<0.05$, with a test value of closeness $(\varphi=-0.967)$.

Table 4 shows that 34 respondents had lighting that did not meet the requirements, including 23 respondents $(67.6 \%)$ who were cases and 11 respondents $(32.4 \%)$ who were controls. Then 26 respondents had lighting that met the requirements, including 7 respondents $(26.9 \%)$ who were cases and 19 respondents $(73.1 \%)$ who were controls. The statistical test results show that the calculated chi square value $(\mathrm{X} 2 \mathrm{hit})=9.774>(\mathrm{X} 2 \mathrm{tab})=$ 3.841 or $\mathrm{p}$ value $=0.002<0.05$, with a test value of closeness $(\varphi=0.404)$. Also obtained the $\mathrm{OR}$ value $=5.675>1$. Logistic regression test results that is 1,000 .

Table 5 shows that 35 respondents have lighting that does not meet the requirements, including 24 respondents $(68.6 \%)$ who are cases and 11 respondents (31.4\%) who are controls. Then 25 respondents had lighting that met the requirements, including 6 respondents (24.0\%) who were cases and 19 respondents (76.0\%) who were controls. The results of statistical tests show that the calculated chi square value $(\mathrm{X} 2 \mathrm{hit})=11.589>\mathrm{X} 2 \mathrm{tab}=$ 3.841841 or $\mathrm{p}$ value $=0.001<0.05$, with $\mathrm{a}$ test value of closeness $(\varphi=0.439)$. Also 
Ifon, Supodo, T., Sunarsih, Munir, S., \& Harun, A. A. DOI: 10.36566/ijhsrd/Vol3.Iss1/68

https://ijhsrd.com/index.php/ijhsrd

e- ISSN: $\mathbf{2 7 1 5 - 4 7 1 8}$

obtained the OR value $=6.909>1$. Logistic regression test results that is 1,000 .

Table 6 shows that of the 28 respondents having ventilation does not meet the requirements, including 19 respondents (67.9\%) who were cases and 9 respondents (32.1\%) were controls. Then 32 respondents had ventilation that met the requirements, including 11 respondents $(34.4 \%)$ who were cases and 21 respondents $(65.6 \%)$ who were controls. The results of statistical tests show that the calculated chi square value (X2hit) $=$ $6.696>\mathrm{X} 2 \mathrm{tab}=3.841841$ or $\mathrm{p}$ value $=$ $0.010>0.05$, with a test value of closeness $(\varphi$ $=0.334)$. Also obtained the $\mathrm{OR}$ value $=$ 4.030> 1.Logistic regression test results that is 0.014 .

Table 1

Association between washing or drying the mosquito nets with the prevalence of pulmonary tuberculosis at the Poasia Health Centre, the Coastal Region of Kendari

City

\begin{tabular}{|c|c|c|c|c|c|c|c|c|c|}
\hline \multirow{4}{*}{$\begin{array}{l}\text { The habit of } \\
\text { washing or } \\
\text { drying the } \\
\text { mosquito } \\
\text { nets }\end{array}$} & \multirow{2}{*}{\multicolumn{4}{|c|}{$\begin{array}{c}\text { Pulmonary TB } \\
\text { prevalence }\end{array}$}} & \multirow{3}{*}{\multicolumn{2}{|c|}{ Total }} & \multicolumn{3}{|c|}{ Statistic test } \\
\hline & & & & & & & 2 & & \\
\hline & \multicolumn{2}{|c|}{ Case } & \multicolumn{2}{|c|}{ Control } & & & $\chi^{2}$ & $\varphi$ & OR \\
\hline & $\mathrm{n}$ & $\%$ & $\mathrm{n}$ & $\%$ & $\mathrm{n}$ & $\%$ & \multirow{4}{*}{$\begin{array}{l}\mathrm{X}^{2} \text { test }=15,017 \\
\mathrm{X}^{2} \text { table }=3,841 \\
\mathrm{P} \text { value }=0.000 \\
\alpha=0.05\end{array}$} & \multirow[t]{4}{*}{0.500} & \multirow{4}{*}{$\begin{array}{l}\mathrm{OR}= \\
9,036 \\
\mathrm{LL} \\
2.802 \\
\mathrm{UL}= \\
29,134\end{array}$} \\
\hline Less & 23 & 74.2 & 8 & 25.8 & 31 & 100 & & & \\
\hline Good & 7 & 24.1 & 22 & 75.9 & 29 & 100 & & & \\
\hline Total & 30 & 50.0 & 30 & 50.0 & 60 & 100 & & & \\
\hline
\end{tabular}

Source: Primary data 2020

Table 2

Association between Cleaning and Drying Habits of Bedding or Mattresses withthe prevalence of pulmonary tuberculosis at the Poasia Health Centre, the Coastal Region of Kendari City

\begin{tabular}{|c|c|c|c|c|c|c|c|c|c|}
\hline \multirow{3}{*}{$\begin{array}{l}\text { The habit of } \\
\text { cleaning or drying } \\
\text { the mattress or } \\
\text { mattress }\end{array}$} & \multicolumn{4}{|c|}{ Pulmonary TB prevalence } & \multirow{2}{*}{\multicolumn{2}{|c|}{ Total }} & \multicolumn{3}{|c|}{ Statistic test } \\
\hline & \multicolumn{2}{|c|}{ Case } & \multicolumn{2}{|c|}{ Control } & & & $\chi^{2}$ & $\varphi$ & OR \\
\hline & $\mathrm{n}$ & $\%$ & $\mathrm{n}$ & $\%$ & $\mathrm{n}$ & $\%$ & \multicolumn{2}{|c|}{$\mathrm{X}^{2}$ test $=11,3800.436$} & $\mathrm{OR}=$ \\
\hline Less & 23 & 69.7 & 10 & 30.3 & 33 & 100 & $\mathrm{x}^{2}$ table $=$ & & $\begin{array}{l}6,571 \\
\mathrm{LL}=\end{array}$ \\
\hline Good & 7 & 25.9 & 20 & 74.1 & 27 & 100 & 3,841 & & 2.109 \\
\hline Total & 30 & 50.0 & 30 & 50.0 & 60 & 100 & $\mid \begin{array}{l}P \text { value }=0.001 \\
\alpha=0.05\end{array}$ & & $\begin{array}{l}\mathrm{UL}= \\
20,479\end{array}$ \\
\hline
\end{tabular}

Source: Primary data 2020. 
Ifon, Supodo, T., Sunarsih, Munir, S., \& Harun, A. A. DOI: 10.36566/ijhsrd/Vol3.Iss1/68

https://ijhsrd.com/index.php/ijhsrd

e- ISSN: $2715-4718$

Table 3

Associationof Drop Out of Treatment with the prevalence of pulmonary tuberculosis at the PuskesmasPoasia, the Coastal Region of Kendari City

\begin{tabular}{|c|c|c|c|c|c|c|c|c|c|}
\hline \multirow{3}{*}{$\begin{array}{l}\text { Drop Out } \\
\text { Treatment }\end{array}$} & \multicolumn{4}{|c|}{ Pulmonary TB prevalence } & \multirow{2}{*}{\multicolumn{2}{|c|}{ Total }} & \multicolumn{3}{|c|}{ Statistic test } \\
\hline & \multicolumn{2}{|c|}{ Case } & \multicolumn{2}{|c|}{ Control } & & & $x^{2}$ & $\varphi$ & OR \\
\hline & $\mathrm{n}$ & $\%$ & $\mathrm{n}$ & $\%$ & $\mathrm{n}$ & $\%$ & $\mathrm{X}^{2}$ test $=56,129$ & $-0,967$ & $\mathrm{OR}=-$ \\
\hline Incomplete & 1 & 3,2 & 30 & 96.8 & 31 & 100 & $\mathrm{X}^{2}$ table $=$ & & $\mathrm{LL}=-$ \\
\hline Complete & 29 & 100.0 & 0 & 0.0 & 29 & 100 & 3,841 & & $\mathrm{UL}=-$ \\
\hline Total & 30 & 50.0 & 30 & 50.0 & 60 & 100 & $\begin{array}{l}\mathrm{P} \text { value = } \\
0.000 \\
\alpha=0.05\end{array}$ & & \\
\hline
\end{tabular}

Source: Primary data 2020.

Table 4

Associationbetween Sunlight Lighting with the prevalence of pulmonary tuberculosis at the Poasia Health Centre, the Coastal Region of Kendari City

\begin{tabular}{|c|c|c|c|c|c|c|c|c|c|}
\hline \multirow{4}{*}{ Sunlight Lighting } & \multirow{2}{*}{\multicolumn{4}{|c|}{$\begin{array}{l}\text { Pulmonary TB } \\
\text { incidence }\end{array}$}} & \multirow{3}{*}{\multicolumn{2}{|c|}{ Total }} & \multicolumn{3}{|c|}{ Statistic test } \\
\hline & & & & & & & \multirow{2}{*}{$\chi^{2}$} & \multirow{2}{*}{$\varphi$} & \multirow{2}{*}{ OR } \\
\hline & \multicolumn{2}{|c|}{ Case } & \multicolumn{2}{|c|}{ Control } & & & & & \\
\hline & $\mathrm{n}$ & $\%$ & $\mathrm{n}$ & $\%$ & $\mathrm{n}$ & $\%$ & $\mathrm{X}^{2}$ test $=9,774$ & 0.404 & $\mathrm{OR}=$ \\
\hline Not eligible & 23 & 67.6 & 11 & 32.4 & 34 & 100 & $\mathrm{X}^{2}$ table $=3,841$ & & 5,675 \\
\hline qualify & 7 & 26.9 & 19 & 73.1 & 26 & 100 & $\mathrm{P}$ value $=0.002$ & & $\begin{array}{l}\mathrm{LL}= \\
1.841\end{array}$ \\
\hline Total & 30 & 50.0 & 30 & 50.0 & 60 & 100 & $\alpha=0.05$ & & $\begin{array}{l}\mathrm{UL}= \\
17,494\end{array}$ \\
\hline
\end{tabular}

Source: Primary data 2020.

Table 5

Association between Humidity with the prevalence of pulmonary tuberculosis at the Poasia Health Centre, the Coastal Region of Kendari City

\begin{tabular}{|c|c|c|c|c|c|c|c|c|c|}
\hline \multirow{4}{*}{ Humidity } & \multirow{2}{*}{\multicolumn{4}{|c|}{$\begin{array}{l}\text { Pulmonary TB } \\
\text { incidence }\end{array}$}} & \multirow{3}{*}{\multicolumn{2}{|c|}{ Total }} & \multicolumn{3}{|c|}{ Statistic test } \\
\hline & & & & & & & & & \\
\hline & \multicolumn{2}{|c|}{ Case } & \multicolumn{2}{|c|}{ Control } & & & $\chi^{-}$ & $\varphi$ & OR \\
\hline & $\mathrm{n}$ & $\%$ & $\mathrm{n}$ & $\%$ & $\mathrm{n}$ & $\%$ & \multirow{4}{*}{$\begin{array}{l}\mathrm{X}^{2} \text { test }= \\
11,589 \\
\mathrm{X}^{2} \text { table }= \\
3,841 \\
\mathrm{P} \text { value }=0.001 \\
\alpha=0.05\end{array}$} & \multicolumn{2}{|c|}{$0.439 \mathrm{OR}=$} \\
\hline Not eligible & 24 & 68.6 & 11 & 31.4 & 35 & 100 & & & 6.909 \\
\hline qualify & 6 & 24.0 & 19 & 76.0 & 25 & 100 & & & $\mathrm{LL}=2,160$ \\
\hline Total & 30 & 50.0 & 30 & 50.0 & 60 & 100 & & & $\begin{array}{l}\mathrm{UL}= \\
22,098\end{array}$ \\
\hline
\end{tabular}

Source: Primary data 2020 
Ifon, Supodo, T., Sunarsih, Munir, S., \& Harun, A. A.

DOI: 10.36566/ijhsrd/Vol3.Iss1/68

https://ijhsrd.com/index.php/ijhsrd

e- ISSN: 2715-4718

Table 6

Association between Home Ventilation with the prevalence of pulmonary tuberculosis at the Poasia Health Centre, the Coastal Region of Kendari City

\begin{tabular}{|c|c|c|c|c|c|c|c|c|c|}
\hline \multirow{3}{*}{ Home Ventilation } & \multicolumn{4}{|c|}{ Pulmonary TB incidence } & \multirow{2}{*}{\multicolumn{2}{|c|}{ Total }} & \multicolumn{3}{|c|}{ Statistic test } \\
\hline & \multicolumn{2}{|c|}{ Case } & \multicolumn{2}{|c|}{ Control } & & & $\chi^{2}$ & $\varphi$ & OR \\
\hline & $\mathrm{n}$ & $\%$ & $\mathrm{n}$ & $\%$ & $\mathrm{n}$ & $\%$ & \multicolumn{2}{|c|}{$\mathrm{X}^{2}$ test $=6,6960.334$} & $\mathrm{OR}=$ \\
\hline Not eligible & 19 & 67.9 & 9 & 32.1 & 28 & 100 & $\mathrm{X}^{2}$ table $=$ & & $\begin{array}{l}4.030 \\
\mathrm{LL}=\end{array}$ \\
\hline qualify & 11 & 34.4 & 21 & 65.6 & 32 & 100 & 3,841 & & 1.372 \\
\hline Total & 30 & 50.0 & 30 & 50.0 & 60 & 100 & $\begin{array}{l}P \text { value }=0.010 \\
\alpha=0.05\end{array}$ & & $\begin{array}{l}\mathrm{UL}= \\
1,839\end{array}$ \\
\hline
\end{tabular}

Source: Primary data 2020

\section{DISCUSSION}

Association between washing or drying the mosquito nets with the prevalence of pulmonary tuberculosis at the PuskesmasPoasia, the Coastal Region of Kendari City

The results showed that there were 8 respondents $(25.8 \%)$ who lacked the habit of locking or drying the mosquito nets but did not suffer from pulmonary TB. This is due to several things including respondents who often apply PHBS in their homes, do not have a history of contact with other TB sufferers, and do a lot of activities under the hot sun. Furthermore, there were also 7 respondents $(24.1 \%)$ who had the habit of locking or drying the mosquito nets in the good category but suffering from pulmonary TB. This is because the respondent has a history of contact with a friend who is suffering from pulmonary TB.

The results of the inferential analysis show that there is a fairly close relationship between the habit of washing or drying the mosquito nets with the incidence of pulmonary tuberculosis at the Poasia Health CenterKendari City Regional Coastal Area. Based on the results of the logistic regression test, it was found that the habit of washing or drying the mosquito nets had a relationship with the incidence of pulmonary tuberculosis at the Poasia Health Center Kendari City Regional Coastal Area.

According to Sidiq (2013) tuberculosis germs can last for 1 to 2 hours in the air, while in a humid and dark place the tuberculosis germs can last for months(13).

Association between Cleaning and Drying Habits of Bedding or Mattresses withthe prevalence of pulmonary tuberculosis at the Poasia Health Centre, the Coastal Region of Kendari City

The results showed that there were still 10 respondents $(25.8 \%)$ who had less habits of cleaning or drying mattresses or mattresses but did not suffer from pulmonary TB. This is due to several things, including respondents who often apply PHBS at home and do not have a history of contact with other TB sufferers. Furthermore, there were also 7 respondents $(24.1 \%)$ who had the habit of cleaning or drying the mattresses or mattresses in the good category but suffering from pulmonary TB. This is because the respondent has a history of contact with a friend who is suffering from pulmonary TB, besides that the respondent has never done any activities under the hot sun.

The results of inferential analysis show that there is a fairly close relationship between the habit of cleaning or drying bedding or mattresses with the incidence of pulmonary tuberculosis at the Poasia Health 
CenterKendari City Regional Coastal Area. The results of this study are in line with the research of Azhar\&Perwitasari (2013) which states that the behavior of not drying the mattress has the risk of being infected with pulmonary tuberculosis by 1,423 times(14).

Based on the results of the logistic regression test, it was found that the habit of cleaning or drying the mats of the bed or mattress was related to the incidence of pulmonary tuberculosis at the Poasia Health Center. Kendari City Regional Coastal Area. Tuberculosis germs cannot tolerate sunlight and air currents. Tuberculosis germs will die within 2 hours by sunlight(15).

Association of Drop Out of Treatment with the prevalence of pulmonary tuberculosis at the Poasia Health Centre, the Coastal Region of Kendari City

In this study, it appears that drop out of treatment is not a risk factor for pulmonary TB incidence. This is because in the case sample, almost all respondents have a complete history of TB treatment drop out. Meanwhile, the control respondents did not experience pulmonary TB pain, so they felt that they did not need to take TB drugs regularly or had to always obey the instructions for ingesting drugs.

The results of inferential analysis show that there is a very small (negligible) relationship between Drop Out of Treatment and the incidence of pulmonary tuberculosis at PuskesmasPoasia. Kendari City Regional Coastal Area. This is not in line with research conducted by Devica (2017) at the Poasia Health Center where the results of their research show that attitudes toward treatment history, namely the habit of taking medication by MDR-TB patients are partially regular and irregular. Based on the results of the logistic regression test, treatment Drop Out had no relationship with the incidence of pulmonary tuberculosis at the Poasia Health CenterKendari City Regional Coastal Area(16).

\section{Association between Sunlight Lighting with the prevalence of pulmonary tuberculosis at the Poasia Health Centre, the Coastal Region of Kendari City}

The results showed that there were 11 respondents $(25.8 \%)$ who had less sunlight but did not suffer from pulmonary TB. This is due to several things including the respondent who has no history of contact with other TB sufferers, the respondent's habit of opening the window and letting the sun directly enter the room. Furthermore, there were also 7 respondents $(24.1 \%)$ who had good sunlight but suffered from pulmonary TB. This is because the respondent has a history of contact with a friend who is suffering from pulmonary TB.

The results of inferential analysis show that there is a fairly close relationship between sunlight lighting and the incidence of pulmonary tuberculosis at the Poasia Health Center Kendari City Regional Coastal Area. This research is in line witha research by Atmosukarto and Soeswati which proves that a house with poor lighting has a significant risk of suffering from tuberculosis 3-7 times compared to a house with good lighting. Nurbaity (2016) also shows that residents whose lighting does not meet the requirements significantly will have a 2.5 times risk of contracting pulmonary tuberculosis compared to residents whose house lighting meets the requirements in East Jakarta(17).

Based on the results of the logistic regression test, it was found that sunlight lighting had no relationship to the incidence of pulmonary tuberculosis at the Poasia Health Center Kendari City Regional Coastal Area. This is not in line with research conducted by Rina Puspita Sari et al (2018) who stated that there was a relationship between lighting and the incidence of pulmonary tuberculosis where the $\mathrm{p}$ value $=$ 0.026 was obtained, at $\alpha=0.05(\mathrm{p} \leq \alpha)(18)$. 
Ifon, Supodo, T., Sunarsih, Munir, S., \& Harun, A. A. DOI: 10.36566/ijhsrd/Vol3.Iss1/68

https://ijhsrd.com/index.php/ijhsrd

e- ISSN: 2715-4718

Association between Humidity with the prevalence of pulmonary tuberculosis at the Poasia Health Centre, the Coastal Region of Kendari City

The results showed that there were 11 respondents $(25.8 \%)$ who had inadequate humidity but did not suffer from pulmonary TB. This is due to several things including the respondent who does not have a history of contact with other TB sufferers, the habit of the respondent always opening the window so that the sun enters the room directly. Furthermore, there were also 6 respondents $(24.1 \%)$ who had the qualifying category of humidity but suffered from pulmonary TB. This is because the respondent has a history of contact with a friend who is suffering from pulmonary tuberculosis, besides that there is no vent in the room or a tightly closed ventilation.

The results of inferential analysis showed that there was a fairly close relationship between humidity and the incidence of pulmonary tuberculosis at the Poasia Health Center Kendari City Regional Coastal Area. So that humidity is a risk factor for the incidence of pulmonary tuberculosis at the Poasia Health CenterKendari City Regional Coastal Area.According to Notoatmodjo (2010), lack of ventilation causes indoor air humidity to rise due to the process of evaporation of fluids from the skin and absorption. This moisture can be a good medium for pathogenic bacteria(19).

This research is in line with the research conducted by Atmosukarto in Bogor City, which shows that residents who have a humidity in their living room that do not meet the requirements have a significant risk of contracting pulmonary tuberculosis 10.7 times that of residents who live in housing that has adequate humidity(20).

Based on the results of the logistic regression test, it was found that humidity had no effect because the $p$ value $>0.05$ was 1,000 .

Association between Home Ventilation with the prevalence of pulmonary tuberculosis at the Poasia Health Centre, the Coastal Region of Kendari City

The results showed that there were still 9 respondents $(25.8 \%)$ who had unqualified house ventilation but did not suffer from pulmonary TB. This is due to several things including the respondent who does not have a history of contact with other TB sufferers, the habit of the respondent always opening the window so that the sun enters the room directly, besides that respondents often practice clean and healthy living habits. Furthermore, there were also 11 respondents (24.1\%) who had the qualifying category of house ventilation but suffered from pulmonary TB. This is because the respondent has a history of contact with a friend who is suffering from pulmonary tuberculosis, besides that he does not open the window to let the sun enter directly in the room

The results of inferential analysis show that there is a small relationship between home ventilation and the incidence of pulmonary tuberculosis at the Poasia Health Center Kendari City Regional Coastal Area. research conducted by Qanata (2018) which states that there is a relationship between home ventilation and the incidence of pulmonary tuberculosis, this study has a risk of getting pulmonary tuberculosis 1,314 times in occupants who have ventilation that do not meet the requirements compared to respondents who are ventilated meet health requirements(21). Based on the test results logistic regressionIt was found that home ventilation had the greatest influence on the incidence of pulmonary tuberculosis in the Puskesmas Poasia in the Coastal Region of Kendari City. This is because the $p$ value is $<0.05$ which is 0.014 .

\section{CONCLUSION}

In this study there is no association betweenDrop Out of treatment with pulmonary TB incidence at the Poasia Health Center in the coastal area of Kendari City. 
Ifon, Supodo, T., Sunarsih, Munir, S., \& Harun, A. A. DOI: 10.36566/ijhsrd/Vol3.Iss1/68

https://ijhsrd.com/index.php/ijhsrd

e- ISSN: 2715-4718

Howeverhumidity variable is the variable that has the strongest or most dominant relationship with the incidence of pulmonary tuberculosis in the Poasia Community Health Center in the coastal area of Kendari City.

\section{REFERENCES}

1. Health department of Republic of Indonesia. National Guideline about Tuberculosis treatment. 2007.

2. Klemens M. Analisis Faktor-Faktor Yang Berhubungan Dengan Kejadian Drop Out Pengobatan Kategori I Pada Penderita Tb Paru Di Wilayah Kerja Dinas Kesehatan Kota Kupang.

3. Carolia N, Mardhiyyah A. Multi Drug Resistant Tuberculosis pada Pasien Drop Out dan Tatalaksana OAT Lini Kedua. Jurnal Majority. 2016;5(2):116.

4. DepKes RI. Pedoman Nasional Penanggulangan Tuberkulosis. 2019.

5. Dinkes Provinsi Sultra. Profil Kesehatan. In: Tenggara DKPS, editor. Kendari: Dinas Kesehatan Provinsi Sulawesi Tenggara; 2019.

6. Nurbaity DP. Penataan Ruang Luar Kampung Nelayan Berbasis Pada Social-Activity (Studi Kasus: Kampung Nelayan Lapulu-Kota Kendari): Institut Teknologi Sepuluh Nopember Surabaya; 2016.

7. Putra A, Husrin S, Mutmainah H. Pola Sebaran Kualitas Air Berdasarkan Kesesuaian Baku Mutu Untuk Biota Laut di Teluk Kendari Provinsi Sulawesi Tenggara. Maspari journal. 2017;9(1):51-60.

8. Kendari DK. Profil Dinas Kesehatan Kota Kendari. In: Kendari DKk, editor. Kendari: Dinas Kesehatan kota Kendari; 2019.

9. Akbar MI. Analysis Of The Needs Of General Practitioners In Public Health Centers Using Health Workload Method. Public Health of Indonesia. 2020;6(2):63-9.
10. Hermawan I. Metodologi Penelitian Pendidikan (Kualitatif, Kuantitatif dan Mixed Method): Hidayatul Quran; 2019.

11. Arikunto S. Prosedur Penelitian Suatu Pendekatan Praktik. 2019.

12. Zakariah MA, Afriani V, Zakariah KM. Metodologi Penelitian Kualitatif, Kuantitatif, Action Research, Research And Development (R n D): Yayasan Pondok Pesantren Al Mawaddah Warrahmah Kolaka; 2020.

13. Sidiq N, Wahiduddin W, Sidik D. Faktor Risiko Lingkungan Terhadap Kejadian Tuberkulosis Paru Di Wilayah Kerja Puskesmas Somba Opu. Jurnal Gizi Masyarakat Indonesia (The Journal of Indonesian Community Nutrition). 2013;9(1):29-35.

14. Perwitasari D, Azhar K. Kondisi Fisik Rumah dan Perilaku dengan Prevalensi Tb Paru di Propinsi DKI Jakarta, Banten dan Sulawesi Utara. Media Penelitian dan Pengembangan Kesehatan. 2013;23(4):20687.

15. Sejati A, Sofiana L. Faktor-faktor terjadinya tuberkulosis. KEMAS: Jurnal Kesehatan Masyarakat. 2015;10(2):122-8.

16. Hapsari DSP, Prasetya F. Studi Kualitatif Perilaku Pasien Tuberkulosis Multi Drugs Resistant Di Wilayah Kerja Puskesmas Poasia Kota Kendari Tahun 2017. (Jurnal Ilmiah Mahasiswa Kesehatan Masyarakat). 2017;3(1).

17. Adnani H, Mahastuti A. Hubungan Kondisi Rumah Dengan Penyakit TBC Paru Di Wilayah Kerja Puskesmas Karangmojo II Kabupaten Gunungkidul Tahun 2003-2006. Jurnal Kesehatan Surya Medika Yogyakarta. 2006:76-9.

18. Sari RP. Factors related to Tuberculosis disease in Walantaka Health Care. Jurnal Ilmu Kesehatan Masyarakat. 2018;7(01):25-32.

19. Notoatmodjo S. Health Behaviour Sciences. 2010. 
Ifon, Supodo, T., Sunarsih, Munir, S., \& Harun, A. A. DOI: 10.36566/ijhsrd/Vol3.Iss1/68

https://ijhsrd.com/index.php/ijhsrd

20. Atmosukarto SS. The effect of household environemnt in distrubution of Tuberculosis. Jakarta, Media Litbang Kesehatan. 2000;9(4).

21. Qanata AM. The relationship between the quality of Tuberculosis services and regular visiting in Pakusari Health Care in Jember District. 2018. 